\title{
The Frontline Is the Past
}

\section{Ukraine on Historical Barricades}

\author{
Sergei V. Perevezentsev
}

\begin{abstract}
This article studies several methods of assessing historical reality"interpretation," "mythologization," "falsification," and "folk history"-and describes all four of them. Based on this classification, the author analyzes the historical substantiation of nation-building in the modern Ukrainian state. The facts and theories used in this article convincingly prove that, unfortunately, by rejecting the data provided by Ukrainian and world science, Ukrainian politicians are building "a single Ukrainian nation" mainly by falsifying history and even using folk history. Such historical policy dramatically whips up political, ethnic, and religious tensions in the country and has negative consequences for the Ukrainian state.
\end{abstract}

Key words: Ukraine, nation-building, historical memory, interpretation, mythologization, falsification, folk history

\footnotetext{
ny nation-building (just as any other social "building," be it state, party, religion, science or something else) is an objective and subjective process at the same time. It is objective to the extent to which the existence of a nation is determined by geographic, climatic, sociopolitical, economic, and external political conditions. But these are no more than prerequisites for the emergence of a

Sergei V. Perevezentsev, Doctor of History, is a Professor at the Department of History of Social and Political Doctrines, Faculty of Political Science, Moscow State University.

serp1380@yandex.ru

SPIN РИНЦ: 7550-6644
}

DOI: $10.31278 / 1810-6374-2018-16-2-36-50$ 
nation, because its actual birth is connected with subjective factors, that is, with the perception of itself in culture (ethnic and linguistic perception), in space (geopolitical perception), in time (historical perception), and in eternity (religious and mythological perception). All four factors are closely intertwined among themselves and are often hard to separate from each other in concrete historical-political or religious-mythological circumstances. But this is not the purpose of this work. We are going to discuss the role of historical knowledge in the nation-building process.

The need for historical substantiation of nation-building is an axiom and needs no proof. The question is what understanding of history is used in each particular case. Given limited possibilities of human learning capacities in general and historical knowledge in particular, one should clearly differentiate between several methods of assessing historical reality. The first one is "interpretation," the second one is "mythologization," and the third one is "falsification."

Interpretation means an attempt to reflect historical reality as precisely as possible on the basis of various sources and certain historical evaluation as part of historical knowledge. Different interpretations of, and academic discussions on, certain issues are a normal, and necessary, phenomenon in history as different historians assess the same historical events, facts and processes differently.

Mythologization tends to absolutize an interpretation as the only correct one, trying to assert it as a generally accepted understanding of the past in the academic world or at the official level. The mythologization of history for state and political purposes is a standard practice in world culture. Moreover, official history of a state or nation has always been and will be a result of mythologization. What matters is the degree of such mythologization, for it must not be based on the falsification of history.

Falsification is an intentional and deliberate distortion of historical reality for the sake of political, academic, group or some other interests. Historical knowledge is falsified through fake documents, the rejection of real historical data, free and baseless judgments and "theories," or intentional contemporization of the historical process. 
The disintegration of the Soviet Union generated one more method-folk history (pop-history, anti-history, etc.). It means a collection of unscientific-fiction writings on historical topics which have inundated the post-Soviet space in the past 20-30 years. There were several reasons for that. One of the most important was active nation-building in former Soviet republics, which generated not even fantastic but truly phantasmagoric historical "theories" and "concepts." The authors of these works created them both in response to the call of their hearts as they had suddenly come to know the "real" history of their people or even entire mankind, and in response to the social demand as in the case of official history books in some countries of the near abroad.

Today all four methods of understanding historical reality are intertwined and often get mixed up, sometimes intentionally. This affects history the most as its achievements remain unnoticed or get distorted for the sake of immediate political interests. Unfortunately, no country in the world has been able to avoid political speculation on history, postSoviet states included, but Ukraine stands out among them.

\section{A SIMPLE NARRATIVE FOR COMPLEX HISTORY}

Ukrainians are a young nation which branched off from the panRussian tree in the second half of the 19th century and finally established itself in the 20th century, largely owing to the purposeful efforts of communist ideologists who sought to reduce the influence of the "Russian factor" in the process of "building a new type of society." The modern state of Ukraine is also a result of the "communist project:" in the past large eastern and southern regions populated predominantly by ethnic Russians and Russian-speaking people as well as western territories, which for centuries had developed in a completely different cultural and historical paradigm, were added to the historical Ukrainian lands for the sake of some economic and political expediency. The independent Ukrainian republic proclaimed in 1991 was not integral and consisted of four large cultural and historical regions: Western Ukraine with Lvov as its center (historical Galicia and Volyn), Central Ukraine with Kiev as its center (historical Little Russia), Novorossiya, 
and Crimea. The center and the west were populated mainly by ethnic Ukrainians, with the Ukrainian language and culture prevailing (even though there were serious differences between traditions, religions, cultures, and languages used by Ukrainians in western and central regions). Novorossiya and Crimea were home mainly to ethnic Russians who spoke the Russian language and cultivated Russian culture. There is also the Transcarpathian region where Orthodox Ruthenians and, separately, Hungarians occasionally raise their voice in support of their national and religious independence.

Finally, there is a complex confessional situation in Ukraine: in addition to the Ukrainian Orthodox Church of the Moscow Patriarchate, there are the self-proclaimed Kiev Patriarchate and the Ukrainian Autocephalous Orthodox Church. The Greek-Catholic (Uniate) Church has reemerged and become very influential in western regions, and numerous Protestant communities have mushroomed across the country during the years of independence. So from the very start modern Ukraine happened to be very heterogeneous ethnically, culturally, religiously, historically, and linguistically (Perevezentsev, 2015: 177-194).

In the first years of Ukraine's independence, its leaders made several attempts to eliminate this heterogeneity. As the ideological basis they used the linguistic and cultural-historical matrix established in western regions and employed to support Ukrainian nationalism since the middle of the 19th century. In the second half of the 20th century it was upheld and actively advanced by the ideologists of Ukrainian nationalist emigration. That matrix provided the groundwork for Ukrainian history as the basis for building "a single Ukrainian nation."

But the problem was that, firstly, the real history of the independent Ukrainian nation is only 150-200 years long, and Ukrainian statehood is even younger; secondly, Western Ukraine, Central Ukraine, Novorossiya, and Crimea have four different histories; and thirdly, the real history of Ukraine and people living on its territory is closely intertwined with the history of Russia and the Russian people. The ideologists of Ukrainian nationalism decided to overcome these obstacles in a way they thought was the simplest by creating Ukrainian 
history anew. In so doing they pursued three tasks: to prove that the Ukrainian nation and Ukrainian statehood are many centuries old; to show the integrity of Ukrainian history throughout that period; and separate the history of Ukraine from the history of Russia and break the historical bond between the two nations.

Folk history became quite instrumental in achieving these goals. In fact, this genre is used by many in Ukraine from pop singers and political propagandists to professors and academicians. But "the biggest discovery" made by Ukrainian folk historians has three components: a) Aryan Ukrainians (proto-Ukrainians) - an ancient Slavic tribe, the primal ancestors of all Slavs; b) Trypillian archaeological cultureAratta civilization founded by Aryan Ukrainians more than five thousand years ago; c) Trypillians made the majority of important discoveries and served as an example for all the subsequent civilizations in the world (for this reason, some advocates of Ukrainian folk history include ancient Sumerians among the ancestors of modern Ukrainians).

All these and many other "discoveries" by folk historians have long been disproved by professional Ukrainian historians. But politicians are not interested to know their opinion simply because professional historians get in the way of the nation-building process and upset their efforts to form an ideology of nationalism, which they have been purposefully inculcating in the everyday historical conscience of Ukrainian people. The myth of Trypillia, ancient Ukrainians and proto-Ukrainians was actively promoted in the 1990s, their authors, some of whom even held academic degrees, received various prizes and promotions, and President Leonid Kuchma went as far as stating that "Ukraine is different from Russia!" (Kuchma, 2003). In the early 2000s, these myths were accepted officially. In 2005, Ukraine's new President Victor Yushchenko said at a mini-Davos international economic forum in Kiev: "A thousand years ago the world's first-ever farming civilization of Trypillia flourished on our land. We find its artifacts in an area stretching from the Dnieper to the Danube and the Vistula. The roots of primal cultures on our European continent got intertwined in that civilization" (Yushchenko, 2005). It was under 
Yushchenko that the myths about Trypillia, Aryan Ukrainians and proto-Ukrainians began to be imposed as truly scientific and the only correct ones (museums were built, archaeological excavations were carried out, books were published, films and television programs were made), and various versions of these myths made their way into school textbooks such as "The History of Ukraine" by P. Kononenko, director of the National Research Institute of Ukrainian History, who has a doctoral degree in philology (Kononenko, 2006). So myths created by folk history became an important part of the official history of the Ukrainian people and the state of Ukraine.

Falsifications played a noticeable role in shaping historical conscience and the official history of the Ukrainian people. Perhaps the most vivid one is the artificial political and ideological construct "Ukraine-Rus," which for the first time was formulated at the end of the 19th and the beginning of the 20th centuries by leading Ukrainian ideologist Mikhail Grushevsky, whose ten-volume work was called "The History of Ukraine-Rus" (published in 1898-1936). Its main purpose was to break historical ties between the Ukrainian and Russian people, destroy their recent common past, and show that the history of Russia was not in any way connected with the Old Russian period, but Ukrainian statehood had ancient roots and that Ukraine was the successor of Kievan Rus. Grushevsky himself admitted that he had invented his concept for purely political and ideological purposes in order to "stress the link between the new Ukrainian life and its old traditions... the old traditional name [Rus-S.P.] is connected with the new term of national revival and movement [Ukraine-S.P.]" (Grushevsky, 1994).

Grushevsky was a professional historian and knew that the Old Russian term 'Ukraine' had never had any ethnic or political significance: in the 12th-16th centuries it was used to denote Russian border territories (Grushevsky wrote about this in the foreword to the first volume of his work (Grushevsky, 1994)). Later, in the 17th19th centuries, the meaning of the term 'Ukraine' changed constantly depending on the concrete historical context and referred to people living in the borderlands regardless of their ethnic background. 
Naturally, differences between Little Russia and Great Russia formed throughout that period due to historical circumstances, but those differences were not so deep, firstly, because they shared the same Orthodox faith and the same Orthodox Church, and secondly, because people in Little Russia were struggling with Poles to preserve their own religious and ethnic identity, which made them publicly declare themselves Russian.

The formation of a separate Ukrainian (just like Belarusian) nation was slow as people continued to identify themselves as Russians and maintained unity with Great Russia for a long time until the second half of the 19th century. But in the middle of the 19th century Little Russian intellectuals for the first time began to draw an image of a separate Ukrainian nation and try to form a Ukrainian national ideology different from the Russian one. As a result, in the middle of the19th century, Little Russian intellectuals began to use the term 'Ukraine' to refer to a separate national-state territory and the term 'Ukrainian' to denote a separate ethnic group.

The false political and ideological construct "Ukraine-Rus" created by Grushevsky became quite popular with Ukrainian nationalists in the 20th century, primarily in Western Ukraine and among Ukrainian emigres, and turned into a key ideological tool of the new state after the separation of Ukraine from the Soviet Union. It is actively used for propaganda and for shaping historical conscience of the modern "Ukrainian nation." Suffice it to listen to incumbent President Pyotr Poroshenko who constantly uses the false "Ukraine-Rus" construct. Stanislav Kulchitsky, a senior researcher at the Institute of History of the Ukrainian Academy of Sciences and the holder of a doctoral degree in history, did not hesitate to say that "Russia emerged as part of Kievan Rus. Speaking of who gave what to whom, we gave Russia everything, even its own history, not of our free will, of course. They have seized six hundred years of Ukraine's history and remain quite confident up to date that it is their history" (Gaizgevskaja, 2018).

It should be noted that this is the same Kulchitsky of whom renowned Ukrainian historian and academician Pyotr Tolochko has said once: "Before the disintegration of the USSR he praised 
collectivization and industrialization, and wrote dissertations about them. After the collapse of the Soviet Union he switched over to the socalled blank spots in history-facts that had been hushed up in Soviet times. While studying them, he became omnivorous and now writes even about Kievan Rus although he has never explored this topic in earnest. He speaks ironically about the theory of Rus, the cradle of three East Slavic peoples, even though there is nothing to be ironic about because this is the gospel truth" (Chmelenok, 2009).

\section{SINCE INFANCY}

Unfortunately, such falsified facts are used in textbooks for Ukrainian schools. Following Grushevsky's behests, they assert the main ideological mythologeme: the history of Russia and the history of Ukraine are two different histories because Russians and Ukrainians have been different peoples since ancient times. For example, S. Vlasov's textbook "The History of Ukraine (Introduction to History)" for 5th grade pupils of secondary schools says: "You already know that the name Rus preceded the name Ukraine for denoting the land populated by Ruthenian Ukrainians. The name Ukraine was for the first time used in chronicles in 1187 with regard to Kiev, Pereyaslavl, and Chernigov. It comes from the word "country" which meant native shore, country, land. Subsequently the name Ukraine supplanted the older one from usage" (Vlasov V, 2013: 47).

The ideology of artificial division into Russian and Ukrainians, who are essentially one people, prevails in all school textbooks in Ukraine. Paragraph 15 titled "The Glory and the Will, or Ukrainian Cossacks in Battles and Marches" in S. Vlasov's textbook focuses on the national liberation war but does not even mention the Pereyaslavl Council of 1654 or the fact that Russia entered into the war with Poland to defend the population of Little Russia. For the sake of political interests, the author prefers to stop the narration in 1648 when Bogdan Khmelnitsky and his troops had achieved the biggest military success. This is followed by a story about the "Ukrainian Cossack state" created on "the biggest part of the Ukrainian lands ... liberated... by Ukrainian warriors from... Polish rule." This is when the author mentions Russia 
but in a negative context, of course. "The Cossack state, Hetmanate, created as a result of the national liberation war existed for more than a hundred years. In 1760-1780 Russian tsars (Hetmanate fell under Russian rule at that time) abolished hetmanship and turned Cossack regiments into Russian army regiments. In 1775 the last remains of the Zaporozhian Sich were done away with" (Vlasov V, 2013: 115-118). It should be noted that the textbook was published at a time when "proRussian" Victor Yanukovich was president.

Things became even worse in the post-Maidan period. The same author's history book for 7th graders does not even mention Russian north-eastern principalities in the 12th century known as a time of political disunity. However, it claims that the main reason for disunity was "the different ethnic composition" of Russian lands (Vlasov, 2015: 98), which suggests that the ethnically different (!) Ukrainian, Belarusian, and Russian peoples already existed in Kievan Rus by the middle of the 12th century. Russia appears in the textbook when the narration comes to the end of the 15th century and is described as the "Tsardom of Muscovy" hostile to "Ukrainians" (a factual mistake because Russia became the tsardom only in the middle of the 16th century), which "under the pretext of consolidating the 'Russian heritage"' started to lay claims to Ukrainian and Belarusian lands (Vlasov, 2015: 168). Again, there is a factual mistake, even two mistakes: a) there were no "Ukrainian" or "Belarusian" lands at that time yet since there was neither Ukraine nor Belarus. There were only lands of the Grand Duchy of Lithuania; b) at the end of the 15th century, the Grand Principality of Moscow did not lay any claims to the so-called "Belarusian" lands, but the author for some reason calls Smolensk "Belarusian" (Vlasov, 2015: 169).

One would think these are just minor things, but it is these minor things that mold the understanding of history and lead young Ukrainians to think for years ahead that Russia has been a historical enemy of Ukraine for centuries. Ukrainians and ethnic Russians have been taught such falsified "minor things" for more than twenty years. As a result, many young and middle-aged Ukrainians think of themselves as a God-chosen nation, the only successors of Kievan 
Rus, and genuine Europeans, thus justifying their "European choice" (Maidan protests are sometimes referred to as Euromaidan). They do not regard Russians even as Slavs, and call them Finno-Ugrians or descendants of Mongols. To them, all Russians are barbaric Asians, "sovoks" and "slaves." There is a dangerous split in the minds of these Ukrainians. On the one hand, they call for abandoning the "Russian" past completely, including the Russian language, Russian literature, and Russian culture. One the other hand, they proclaim some of the Russian writers, painters, composers, and inventors Ukrainian. The same dangerous split of mind exists in everyday life: calls for severing all ties with Russia go hand in hand with trips to Russia for employment purposes.

So most of the historical and political constructs offered to the citizens of Ukraine today are based on lies and falsifications. They do not help to consolidate the country but on the contrary disunite it. While in the 1990s, the Ukrainian authorities somehow managed to keep the balance between conflicting regions and traditions, the situation became much more complex after nationalist political circles had become active with the support of Western politicians. Moreover, a real civil war broke out in 2014 between the proponents and opponents of an artificial "single Ukrainian nation."

\section{WHAT'S NEXT?}

There is yet one more serious obstacle to Ukraine's nation-building efforts: disagreements between the advocates of "the political Ukrainian nation," which lacks ethnic homogeneity (i.e. "Euroukrainians"), and the supporters of an ethnically homogenous Ukrainian nation (i.e. nationalists). The former initially intended to eventually give up their ethnic identity, not only as Russians, Jews, Hungarians, Ruthenians, but also (what outrage!) as Ukrainians ("We are Europeans!"). Naturally, nationalists who publicly shout "Ukraine above all!," "Glory to the nation!," and "Death to enemies!" are ready to tear the "Euroukrainians" heads off even for allowing such a thought. This is why "Euroukrainians" are at a loss today: In order to overcome natural historical, spiritual, cultural, and even family ties between people in 
Ukraine and Russia, they have to rely on the ideology and practices of Ukraine nationalism, but its strengthening will destroy all the "achievements" of "European integration" and lead to the triumph of barefaced Nazism. The more furious "Euroukrainians" get about Russia, the more influence nationalists gain in the country. The problem is that in their struggle for what they believe to be national history, the national language and national ideals, triumphant nationalists are destroying not only their archenemies-Russians-but also a) their own Ukrainian people and their own Ukrainian statehood, and b) the so-called "European choice" by strongly opposing the European Union's generally accepted ideology designed to eliminate national, state, ideological, gender and other differences.

The cynicism of the incumbent Ukrainian authorities is underscored by the fact that they are well aware of all these contradictions. However using the ideology of "European integration" as a smokescreen, they continue their purposeful efforts to create an artificial "single Ukrainian nation," which they can do only by killing all the dissenters. So while before the authorities persecuted only people living in Novorossiya and Crimea, now they are conducting an uncompromising war to exterminate the population of the Donetsk and Lugansk regions, as well as "separatists" in Ukraine itself, being particularly hateful towards Crimeans, constantly cutting them off from water and power supplies and blocking transport routes to the peninsula. There is also an ideological war going on for history, language, culture, faith, customs, and traditions. It only looks like a war of memory, while in fact it is a war for the present and future of Ukraine. The Ukrainian authorities keep extending this war: at first they were battling with Russia alone, now they are fighting Hungary, Poland, and even Romania.

What are possible scenarios? There are several of them.

1. Nationalists, who have their own armed formations and the support of oligarchs and Western allies, are gaining more influence, while Ukraine remains a unitary state. But as such Ukraine can only exist as an ethnocratic totalitarian entity populated solely by ethnic Ukrainians or those who have given up their "natural" ethnicity in favor of "Ukrainness" and civil 
rights. Linguistic and cultural diversity, tolerance, and the freedom of speech are banned; dissent and national movement are suppressed by force; all those opposing such a "Ukrainian" choice have been sent out of the country or physically destroyed.

2. A unitary ethnocratic state cannot exist for a historically long time. As a result, conflicts will multiply inside the country and Ukraine will gradually (or abruptly) fall apart into several state entities along the existing or new historical and cultural borders. In the future, some of the borderlands will most likely be absorbed by neighboring countries with which the local population has cultural and historical bonds. Unfortunately, conflicts are unavoidable under this scenario.

3. Ukraine is a state that has been integrated into "European life," has accepted the so-called "European values" and is waiting to be admitted to the European Union. Society has agreed with the need to create "a political Ukrainian nation" and, therefore, quickly overcome ethnic, cultural, national, religious and other differences. Ukrainian nationalism has been pushed to the sidelines of the historical process and left entirely to fringe groups. However the anti-Russian policy and antiRussian propaganda continue; all people who openly identify themselves as Russian and adhere to the Russian spiritual and cultural tradition are ostracized.

4. Ukraine is a democratic state, free of ideological diktat and shares open borders with both united Europe and Russia. Inside the country each of the federal territories has ample powers, with ethnic Russians, Hungarians, Ruthenians, Gagauz and others enjoying broad rights. On the one hand, this allows them to continue their ethnic and cultural development, and on the other hand, enables Ukraine to carry out national development plans.

Which of the four scenarios is more realistic? At this point, it is the first or the second one. Even the third scenario looks utopian because Ukrainian nationalists who are running the show today will never agree with such an option. The fourth scenario appears to be even 
more implausible, like some folk history. But then, anything can be possible. In fact, Crimea has made its way back home quite peacefully.

"Let others learn from his example!" Russian poet Alexander Pushkin wrote. Ukraine is an example for all of us citizens of Russia to learn from in many respects. Firstly, it is absolutely clear that common historical conscience is the foundation of a country's integrity upon which rest not only statehood but the historical existence of a nation or a commonwealth of nations. Common historical conscience is a set of important historical events assessed by all people in the same way due to centuries of shared destiny. The acceptance of such an assessment makes them a nation. Common historical conscience also means that a person feels like being part of something grand and important, and that present generations share the historical destiny of their nation and understand their historical and moral responsibility for their country and its people before those who were before them and those will come after them.

Secondly, common historical conscience cannot arise out of lies or falsifications. Such fakes as "The Book of Veles," "Djagfar Tarikhy," the phantasmagoric "New Chronology," "Hyperborea," and other reportedly "historical" nonsense only ruin common historical memory.

Thirdly, one must not go to the other extreme and rely entirely on some "objective historical knowledge," waving away national priorities in history. This approach is still quite common among Russian historians and one can hear sometimes that the feeling of patriotism is a serious obstacle to obtaining "objective historical knowledge." It is for this reason that some deny Mikhail Lomonosov's contribution to the development of history as a science and denounce his historical views as unscientific.

People's historical conscience can be messed up completely under the guise of "objectivity." The so-called historical-cultural standard, which applies to all history textbooks for schools, includes a tentative list of Difficult Questions of History. Drawing up such a list may be 
useful as there are indeed many controversial problems in history that have no straightforward solutions. Here are two examples of "difficult" questions: "The existence of the Old Russian nation and the recognition of Old Russia's heritage as a common foundation in the history of Russia, Ukraine, and Belarus" and "The incorporation of Ukraine into Russia (causes and consequences)" (Standart, 2015). But they became difficult because of the Ukrainian and Belarusian nationalistic circles which started to interpret them for the sake of their own nation-building purposes. In other words, Russian schoolchildren are encouraged to look at these problems not through the lens of Russian interests but through the eyes of Ukrainian and Belarusian nationalists. The list contains one more question: "Alexander Nevsky's choice in favor of subordinating Russian lands to the Golden Horde." So pupils are urged to think whether Alexander Nevsky was a hero or a traitor. As a result, key components of the Russian people's common historical conscience are called into question under the pretext of some sort of "objectivity."

And so we have to say this again: the question of developing a new official interpretation of Russia's history, which would facilitate further existence and development of common historical conscience, remains open. But this is a topic for a separate big discussion.

\section{References}

Chmelenok, M., 2009. Pyotr Tolochko: Istoriyu pitayutsya podmeniti mifami. Narodna Pravda.ua, 22 November. Available at: http://narodna.pravda.com.ua/ politics/4b090cea59eb7/

Gaizgevskaja, T., 2018. Rossiya - chast Kievskoy Rusi: ukrainskiy istorik poyasnil, "chto kto komu otdal. Obozrevatel.ua. 22 January. Available at: https://www. obozrevatel.com/society/rossiya-chast-kievskoj-rusi-ukrainskij-istorik-poyasnil-chto-kto-komu-otdal.htm

Grushevsky, M., 1994. Istoriya Ukraini-Rusi. T. 1. Kiev: Naukova dumka. Available at: http://litopys.org.ua/hrushrus/iur10101.htm

Kononenko, P., 2006. Ukrainoznavstvo. Kiev: Milenium. 
Kuchma, L., 2003. Ukraina - ne Rossiya. Moskwa: Vremya.

Perevezentsev, S., 2015. Rodstvo po istorii. Moskwa: Izdatelstvo "FIV".

Standart, 2015. Istoriko-kuiturniy standart, Rossiyskoe istoricheskoe obschestvo. Available at: https://historyrussia.org/proekty/kontseptsiya-novogo-uchebnometodicheskogo-kompleksa-po-otechestvennoj-istorii/istoriko-kulturnyjstandart

Vlasov, V., 2013. Istoria Ukrainy (Vvedenie v istoriyu): uchebnik dlya 5-go klassa obscheobrazovatelnih uchrezgdeniy. Kiev: Genesa.

Vlasov, V., 2015. Istoria Ukrainy: pidruchnik dlya 7 klasu zagalnoosvitnih navchalnih zakladiv. Kiev: Genesa.

Yuschenko, V., 2005 Yuschenko pereputal apostolov Petra i Andreya i rasskazal investoram o Tripolie. Ukrainskaya Pravda, 16 June. Available at: https://www. pravda.com.ua/rus/news/2005/06/16/4389330/ 